\title{
Connexin43 and AMPK Have Essential Role in Resistance to Oxidative Stress Induced Necrosis
}

\author{
Chunshan Zhao, ${ }^{1}$ Jinnv Fang, ${ }^{2}$ Chunguo $\mathrm{Li}^{3}$ and Min Zhang ${ }^{1}$ \\ ${ }^{1}$ Beihua University, Jilin, Jilin, China \\ ${ }^{2}$ Department of Preventive Medicine, College of Medicine, Yanbian University, Yanji, Jilin, China \\ ${ }^{3}$ Jilin City Central Hospital, Jilin, Jilin, China \\ Correspondence should be addressed to Min Zhang; 1874751233@qq.com
}

Received 20 June 2017; Accepted 3 October 2017; Published 27 November 2017

Academic Editor: Rui Liu

Copyright (C) 2017 Chunshan Zhao et al. This is an open access article distributed under the Creative Commons Attribution License, which permits unrestricted use, distribution, and reproduction in any medium, provided the original work is properly cited.

Reactive oxygen species (ROS) induced oxidative stress leads to cell damage and neurological disorders in astrocytes. The gap junction protein connexin $43(\mathrm{Cx} 43)$ could form intercellular channels in astrocytes and the expression of $\mathrm{Cx} 43$ plays an important role in protecting the cells from damage. In the present study, we investigated the contribution of Cx43 to astrocytic necrosis induced by the ROS hydrogen peroxide $\left(\mathrm{H}_{2} \mathrm{O}_{2}\right)$ and the mechanism by which AMPK was involved in this process. Fluorescence microscopy, flow cytometry, and western blot were used quantitatively and qualitatively to determine the cell apoptosis, necrosis, and protein expression. Lack of $\mathrm{Cx} 43$ expression or blockage of $\mathrm{Cx} 43$ channels resulted in increased $\mathrm{H}_{2} \mathrm{O}_{2}$-induced astrocytic necrosis, supporting a cell protective effect of functional Cx43 channels. Our data suggest that AMPK is important for Cx43mediated ROS resistance. Inhibition of AMPK activation results in reduction of necrosis and ROS production. Taken together, our findings suggest that the role of $\mathrm{Cx} 43$ in response to $\mathrm{H}_{2} \mathrm{O}_{2}$ stress is dependent on the activation of AMPK signaling pathways and regulates ROS production and cell necrosis.

\section{Introduction}

Astrocytes are the most abundant nonneuronal cell type in the central nervous system [1]. They play an important role in glutamate uptake, potassium ion buffering, and antioxidant protection for neurons $[2,3]$. The gap junction protein connexin $43(\mathrm{Cx} 43)$ is essential for the function of astrocytes and highly expressed inside the cell [4]. Cx43 can form gap junction channels as well as hemichannels. Gap junctions allow the passive intercellular diffusion of small molecules [5]. Oxidative stress is a result of the imbalance between reactive oxygen species (ROS) production and antioxidant activity. High level of ROS can also be generated under various conditions, leading to potential damage [6]. Cx43 expression in astrocytes behaved as the center of antioxidative stress [7]. Previous research indicated that $\mathrm{Cx} 43$ expression protected the C6 cells from $\mathrm{ROS} \mathrm{H}_{2} \mathrm{O}_{2}$ stress [3]. What is more, knockdown of $\mathrm{Cx} 43$ increases cell death induced by $\mathrm{H}_{2} \mathrm{O}_{2}$. A signaling pathway which leads to caspase- 3 activation is involved in this protection [8]. However, the mechanism underlying this $\mathrm{Cx} 43$-mediated ROS resistance to cell apoptosis and necrosis in astrocytes has not been well distinguished and quantified. The upstream activator of mechanistic target of rapamycin (mTOR) plays an important role in cell growth and apoptosis, mTOR activity is regulated by many kinases, and AMP-activated protein kinase (AMPK) is the most crucial one in this process. Phosphorylation of AMPK is likely to activate this signal pathway, and more existing regulators need to be discovered. Therefore, we investigated if $\mathrm{H}_{2} \mathrm{O}_{2}$-induced cell damage is owing to apoptosis or necrosis and AMPK activity in the process as well. In the present study, we used MTT assay and fluorescence microscopy to examine the role of $\mathrm{Cx} 43$ expression and activity in $\mathrm{H}_{2} \mathrm{O}_{2}$-induced astrocytic death. Further, the flow cytometry indicated that most of the cell damage was necrosis during the $\mathrm{H}_{2} \mathrm{O}_{2}$ stress, and it is well correlated with the expression of $\mathrm{Cx} 43$. Phosphorylation of AMPK is involved in $\mathrm{H}_{2} \mathrm{O}_{2}$ stress and ROS production. Specific inhibitor of AMPK could reduce the amount of cell caused by necrosis and decrease ROS production. Altogether, we concluded that $\mathrm{Cx} 43$ expression 
is essential to modulate $\mathrm{H}_{2} \mathrm{O}_{2}$-induced cell necrosis and activation of AMPK is involved in the process.

\section{Materials and Methods}

2.1. Astrocyte Culture. Astrocytes were isolated from early postnatal cortices (P1-P3). All the brain from littermates of heterozygous mating was processed. The details were described previously [9]. Briefly, cortices were dissected and triturated in cold HBSS. Cell suspension was diluted to fresh HBSS, treated with trypsin-EDTA and passed through a $40 \mu \mathrm{m}$ cell strainer. Cells were spun down and resuspended in prewarm DMEM media (GIBCO) supplemented with $10 \%$ FBS and seeded $2 \times 10^{6}$ cells into flasks. The medium was replaced every two days. Cell cultures were maintained prior to experiments. Confluence of the astrocyte culture was usually $70 \%-90 \%$ before the experiments were performed. And one should make sure all the experiments were carried out on confluent astrocytes. All the chemicals were purchased from Sigma Aldrich unless indicated otherwise.

2.2. Cytotoxicity Assay. The cytotoxicity of $\mathrm{H}_{2} \mathrm{O}_{2}$ was measured by MTT assay as previously reported [10]. Briefly, $1 \times$ $10^{4}$ astrocyte cells were seeded onto 96-well microplates and one kept growing until confluent stage. The cells were washed briefly and resuspended in medium with indicated concentrations of $\mathrm{H}_{2} \mathrm{O}_{2}$ for $45 \mathrm{~min} .20 \mu \mathrm{L}$ of $5 \mathrm{mg} / \mathrm{mL}$ MTT in PBS working solution was added to each well and incubated at $37^{\circ} \mathrm{C}$ for another 4 hours. The optical density at $570 \mathrm{~nm}$ was measured with microplate reader. Cell viability was calculated as a percentage of viable cells in $\mathrm{H}_{2} \mathrm{O}_{2}$-treated groups versus untreated control.

2.3. Cx43 Gap Junction Blocker, AMPK Inhibitor, and Transient siRNA Transfection Treatment. In order to measure the effect of gap junction blockers on $\mathrm{H}_{2} \mathrm{O}_{2}$-induced cell death, gap junction $\mathrm{Cx} 43$ blocker carbenoxolone ( $\mathrm{Cbx}$ ) at the concentration of $100 \mu \mathrm{M}$ was added $30 \mathrm{~min}$ earlier before $\mathrm{H}_{2} \mathrm{O}_{2}$ treatment. AMPK inhibitor, Compound $\mathrm{C}$ (Comp C), at the concentration of $10 \mu \mathrm{M}$ was added $30 \mathrm{~min}$ earlier as well. Transient siRNA transfection was used to knock down Cx43 as described protocol [11].

2.4. Measurement of Reactive Oxygen Species (ROS) Production. ROS level was measured using 2,7-dichlorofluorescein diacetate (DCFDA) fluorescence dye as described [12]. Cells were treated with $1 \mu \mathrm{M}$ DCFDA at $37^{\circ} \mathrm{C}$ for $30 \mathrm{~min}$ and passed through a $40 \mu \mathrm{m}$ cell strainer. Fluorescence intensity was measured by flow cytometry (FACS Calibar; BectonDickinson). The numbers of each analysis containing at least $1 \times 10^{4}$ cells were quantified and analyzed using CellQuest software according to the manufacture.

2.5. Western Blotting Analysis. Astrocytes were digested with $0.25 \%$ Trypsin/EDTA and resuspended in RIPA Lysis Buffer (50 Mm Tris- $\mathrm{HCl}$ pH 8.0, $150 \mathrm{mM} \mathrm{NaCl}, 1 \%$ Nonidet P-40, $0.5 \%$ sodium deoxycholate, $0.1 \%$ sodium dodecyl sulphate (SDS), $1 \mathrm{mM}$ sodium orthovanadate, and protease inhibitors tablet from Roche). The samples were put on ice for $30 \mathrm{~min}$ and then centrifuged at $14,000 \mathrm{~g}$ for $25 \mathrm{~min}$ at $4^{\circ} \mathrm{C}$. The supernatants were subjected to protein concentration assay by Bradford methods [13]. Equal amount of $100 \mu \mathrm{g}$ protein was loaded to SDS-PAGE gel and transferred to nitrocellulose membrane, subject to a standard protocol by blocking and antibody treatment [14]. Briefly, the nitrocellulose membrane was blocked in 5\% nonfat milk for 1 hour, subject to primary antibody overnight, and the membrane was washed three times in PBS. Antibodies including Cx43 (1:1000), GAPDH (1:1000) (Neomarkers), and p-AMPK and AMPK (Santa Cruz) were used here. A horseradish peroxidase-conjugated second antibody was added and the membrane was incubated $1 \mathrm{~h}$, followed by ECL chemoluminescence system. The intensity of the signals was semiquantified by ImageJ software, downloaded from the National Institute of Health (USA) (NIH Image-free download available at https://imagej .nih.gov/ij/download.html). The relative expression was normalized to GAPDH or AMPK expression [15].

2.6. Cell Death and Apoptosis Analysis. DAPI and TUNEL double staining were used here for cell death analysis. The result was visualized under an inverted fluorescence microscope. Random fields of view photographed were selected. Cell death was determined and expressed as percentage TUNEL positive cells of total cells, which was determined by DAPI staining.

The apoptosis and necrosis analysis has been done previously by flow cytometry method by Annexin $\mathrm{V}$ propidium iodide (PI) detection [16]. The cells were washed with ice-cold PBS and resuspended in binding buffer at the concentration of $1 \times 10^{6}$ cells $/ \mathrm{mL}$. Staining was done in dark for $15 \mathrm{~min}$ and then immediately analyzed using flow cytometry (FACS Calibur; Becton-Dickinson). $1 \times 10^{4}$ cells of each analysis were quantified and analyzed using CellQuest software according to the manufacturer.

2.7. Statistical. The results were presented as the average \pm standard deviation (SD). Student's $t$-test was used to evaluate the response to a change in conditions. $P<0.05$ is considered significant $(*) ; P<0.01$ is considered highly significant $(* *)$.

\section{Results}

3.1. $\mathrm{H}_{2} \mathrm{O}_{2}$ Decreased Cell Viability and Expression of Cx43, Inducing Cell Death in Astrocytes. To determine the cytotoxic effects of $\mathrm{H}_{2} \mathrm{O}_{2}$ in astrocytes, MTT assay was used. Cells were exposed to various concentrations of $\mathrm{H}_{2} \mathrm{O}_{2}$ as shown in Figure 1(a). Cytotoxic effect is weak if the concentration of $100 \mu \mathrm{M} \mathrm{H}_{2} \mathrm{O}_{2}$ was treated. Thus, the concentration more than $100 \mu \mathrm{M}$ was highly significant compared with control group.

Astrocytes were treated with $\mathrm{H}_{2} \mathrm{O}_{2}$ for $45 \mathrm{~min}$ in serumfree medium and then harvested immediately after treatment, while untreated (control) cells were maintained in the same condition. There was a twofold reduction in $\mathrm{Cx} 43$ level with $100 \mu \mathrm{M} \mathrm{H}_{2} \mathrm{O}_{2}$ treatment, and the expression decreased with increasing $\mathrm{H}_{2} \mathrm{O}_{2}$ treatment, and the level was further quantified in the histogram shown in Figures 1(b) and 1(c).

The result demonstrated that cell had a marked resistance to low concentration of $\mathrm{H}_{2} \mathrm{O}_{2}$. Exposure of cells to 


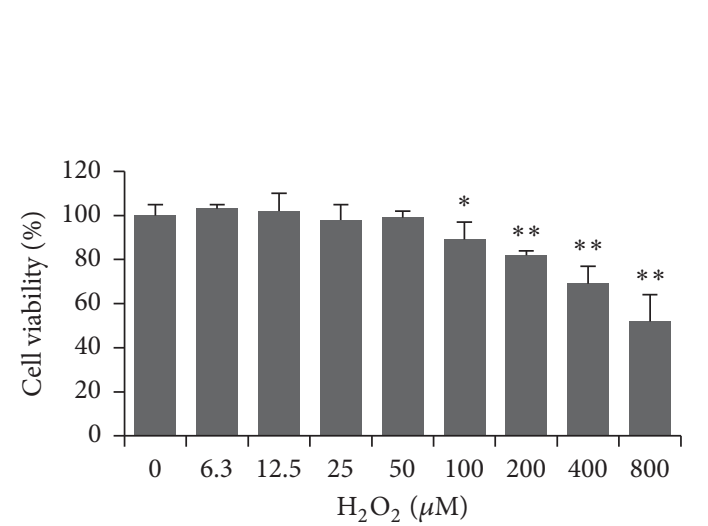

(a)

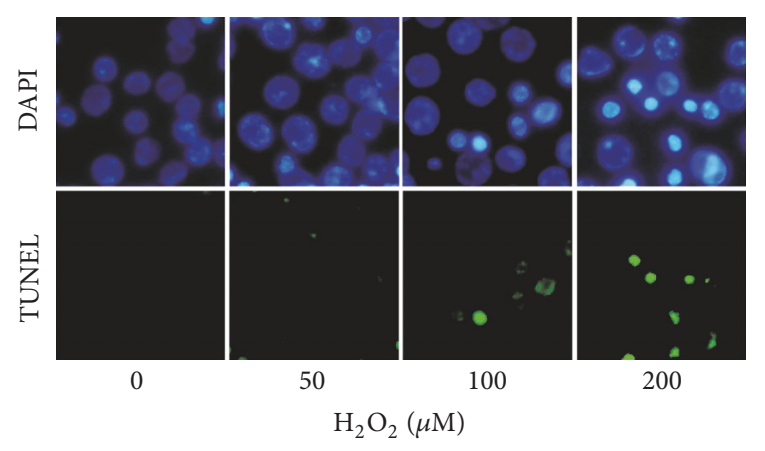

(c)

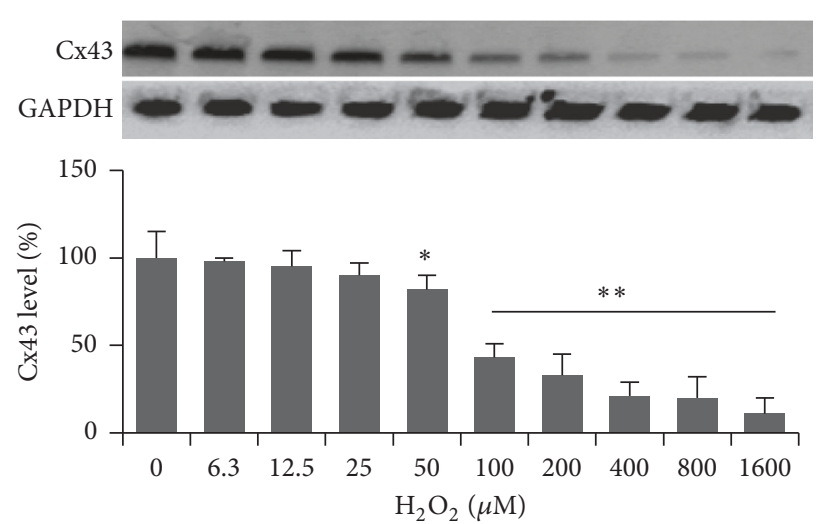

(b)

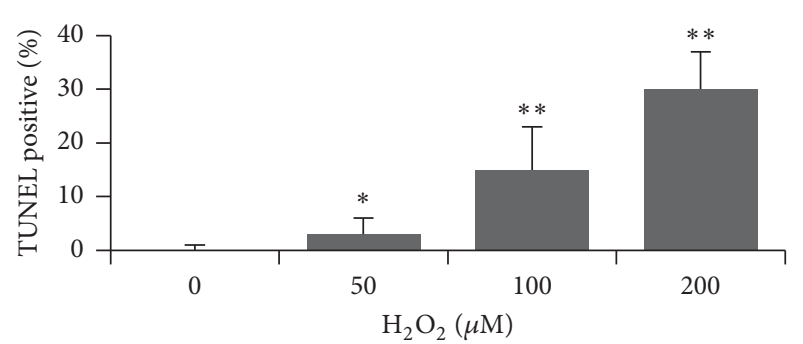

(d)

FIGURE 1: $\mathrm{H}_{2} \mathrm{O}_{2}$ decreased cell viability and expression of $\mathrm{Cx} 43$, inducing cell death in astrocytes. (a) Cytotoxicity of $\mathrm{H}_{2} \mathrm{O}_{2}$ in MTT assay. (b) Presentative bands and quantification expression of $\mathrm{Cx} 43$ by western blotting. (c) Cell death was measured by DAPI and TUNEL costaining. Scale bar: $10 \mu \mathrm{m}$. (d) TUNEL labeling cells were quantified by counting cells from random fields $(n>300$ cells). $*$ indicated $p<0.05 ; * *$ indicated $p<0.01$.

$200 \mu \mathrm{M} \mathrm{H}_{2} \mathrm{O}_{2}$ resulted in morphological changes as well as cell damage, including DNA fragmentation and nuclear condensation, Figure 1(d). TUNEL positive cells were further quantified in Figure $1(\mathrm{~d})$. Taken together, these results suggested $\mathrm{H}_{2} \mathrm{O}_{2}$-induced astrocytes injury and death was specific, in a concentration dependent manner, and it is likely to involve in $\mathrm{Cx} 43$ in the mediation.

3.2. siRNA Knockdown or Blocking Cx43 by Cbx Enhanced $\mathrm{H}_{2} \mathrm{O}_{2}$-Induced Necrosis in Astrocytes. It has been previously reported that $\mathrm{Cx} 43$ leads to a protection effect in apoptosis and necrosis in primary astrocytes [17]. However, $\mathrm{H}_{2} \mathrm{O}_{2}$ induced cell damage in astrocytes has not been well quantified. To determine whether functional $\mathrm{Cx} 43$ expression is important for protection against $\mathrm{H}_{2} \mathrm{O}_{2}$, astrocytes were exposed to the $\mathrm{Cx} 43$ channel blockers $\mathrm{Cbx}$ or transfected with siRNA to knock down $\mathrm{Cx} 43$. The results confirmed that siRNA knockdown or its inhibitor Cbx decreased $\mathrm{Cx} 43$ expression in astrocytes. $\mathrm{H}_{2} \mathrm{O}_{2}$ treatment further enhanced this effect of $\mathrm{Cx} 43$ reduction, Figures 2(a) and 2(b). Secondly, it is not clear whether the decreased $\mathrm{Cx} 43$ expression in astrocytes is essential for their resistance to $\mathrm{H}_{2} \mathrm{O}_{2}$-induced apoptosis and necrosis. The flow cytometry method for double staining was used here. siRNA knockdown or Cbx treated in astrocytes produced more necrosis cells, $17.28 \%$ and $10.24 \%$ of the total number of cells, respectively. While exposed to $100 \mu \mathrm{M} \mathrm{H}_{2} \mathrm{O}_{2}$, both necrosis and apoptosis cells were produced. Astrocytes lacking Cx 43 exhibited 35.45\% and $18.38 \%$ cell necrosis at this concentration. Only $9.18 \%$ of astrocytes exposed with $\mathrm{H}_{2} \mathrm{O}_{2}$ were necrosis as shown in Figure 2(c). The enhanced percentage of necrosis is correlated with $\mathrm{Cx} 43$ reduction. This result indicates that $\mathrm{Cx} 43$ deficient astrocytes are more sensitive to $\mathrm{H}_{2} \mathrm{O}_{2}$-induced necrosis. Taken together, it suggests that expression of $\mathrm{Cx} 43$ is important for cell survival, especially to necrosis in response to $\mathrm{H}_{2} \mathrm{O}_{2}$.

3.3. siRNA Knockdown or Blocking Cx43 by Cbx Enhanced $\mathrm{H}_{2} \mathrm{O}_{2}$-Induced ROS Production. $\mathrm{H}_{2} \mathrm{O}_{2}$ is well known to produce free radicals to inhibit gap junctional intercellular communication [18]. Next, how Cx43 expression contributes to the $\mathrm{H}_{2} \mathrm{O}_{2}$-induced $\mathrm{ROS}$ was determined. As shown in Figure 3, astrocytes lacking Cx43 exhibited 6.84\% and 4.29\% ROS production at this concentration, while it increased to $76.15 \%$ and $60.25 \%$ combined with $\mathrm{H}_{2} \mathrm{O}_{2}$ treatment, which is significantly higher than the $22.83 \%$ in the control group. Here, the data indicated that $\mathrm{H}_{2} \mathrm{O}_{2}$ increased ROS production, and reduction of $\mathrm{Cx} 43$ enhanced it. 


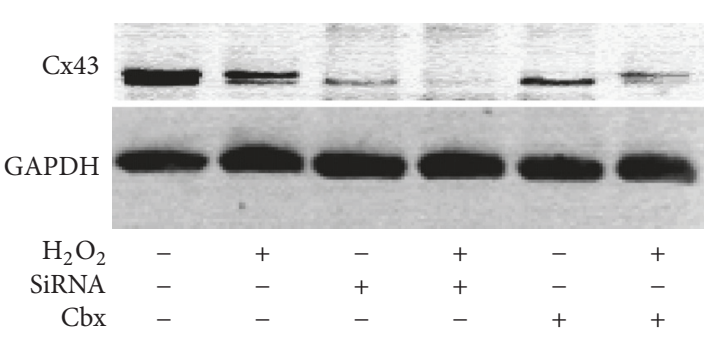

(a)
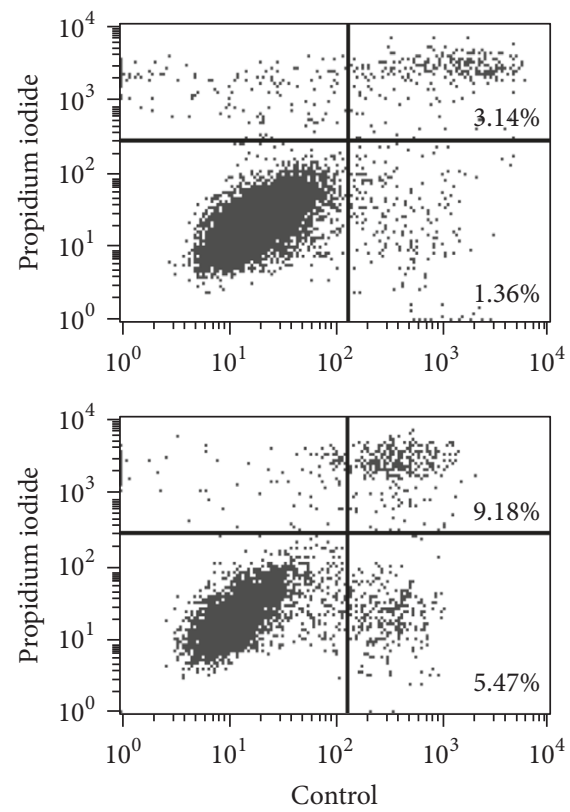

Annexin V FITC
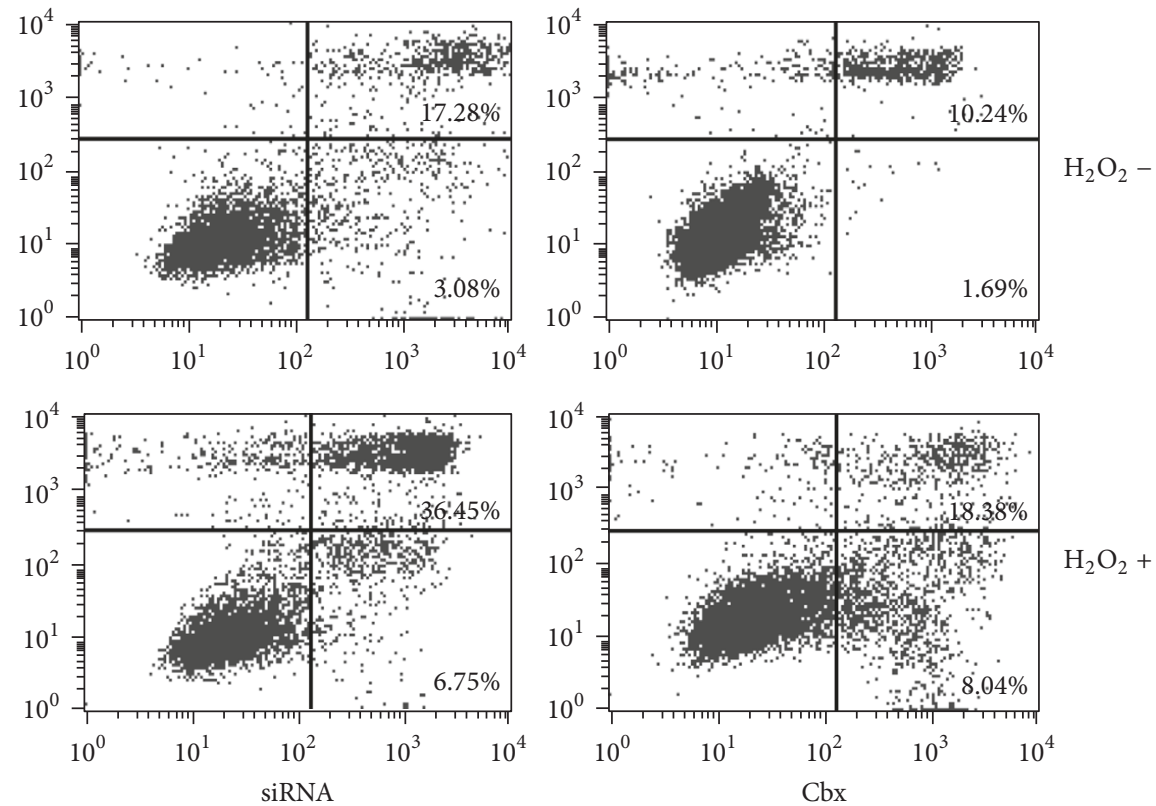

Annexin V FITC

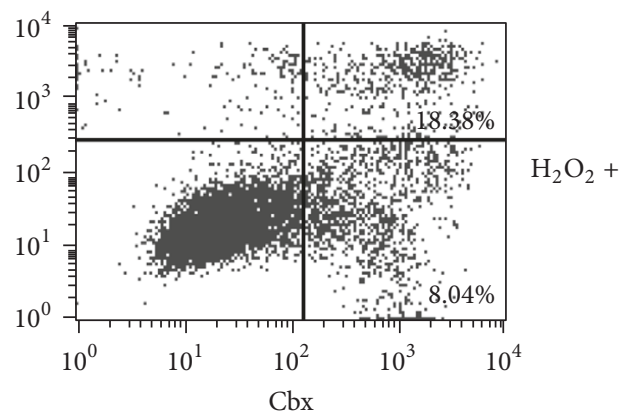

Annexin V FITC

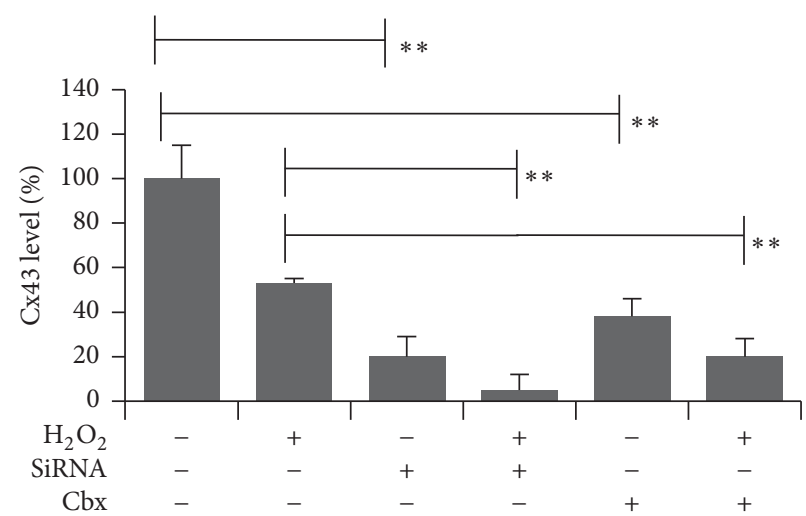

(b)

(c)

FIGURE 2: siRNA knockdown or blocking $\mathrm{Cx} 43$ by Cbx enhanced $\mathrm{H}_{2} \mathrm{O}_{2}$-induced necrosis in astrocytes. (a) Presentative bands expression of Cx43 was detected by western blotting. (b) Quantification of Cx43/GAPDH by membrane intensity. (c) Necrosis and apoptosis cells were stained by Annexin V FITC and PI and determined by flow cytometry ( $n=10,000$ cells). $*$ indicated $p<0.05 ; * *$ indicated $p<0.01$.

3.4. Attenuating $\mathrm{H}_{2} \mathrm{O}_{2}$-Induced Necrosis in Astrocytes Was Involved in AMPK Signal Pathway. At present, the signaling pathway that is involved in ROS production has been investigated, and AMPK is an important sensor that controls various signaling pathway [19]. Here, the effect of $\mathrm{H}_{2} \mathrm{O}_{2}$ on AMPK activation was examined. As shown in Figures 4(a) and $4(\mathrm{~b}), \mathrm{H}_{2} \mathrm{O}_{2}$ treatment leads to an increase of AMPK phosphorylation, but AMPK inhibitor Comp C blocks this phosphorylation. Note that reduction of $\mathrm{Cx} 43$ activated the phosphorylation even further. To address whether AMPK activation correlated with $\mathrm{H}_{2} \mathrm{O}_{2}$-induced necrosis and ROS production, flow cytometry was used and the data was quantified in Figures 4(c) and 4(d). Interestingly, Comp C treatment also markedly inhibited $\mathrm{H}_{2} \mathrm{O}_{2}$-induced necrosis and ROS production. Taken together, these data suggest that
AMPK is involved in $\mathrm{H}_{2} \mathrm{O}_{2}$-induced cell necrosis and ROS production.

\section{Discussion}

It is well known that $\mathrm{H}_{2} \mathrm{O}_{2}$ exposure increases ROS production inside cells. In this paper, astrocytes under oxidative challenge with $\mathrm{H}_{2} \mathrm{O}_{2}$ resulted in decreased cell viability, which is consistent with previous studies in control vehicletreated cultures [20]. Cell damage, including DNA fragmentation and nuclear condensation, was also observed [20].

Here, the relationship between $\mathrm{H}_{2} \mathrm{O}_{2}$ exposure and $\mathrm{Cx} 43$ was investigated. $\mathrm{Cx} 43$, one of the predominant connexins for astrocytes, decreased expression at a dose-dependent manner. In addition, the TUNEL straining result indicated 



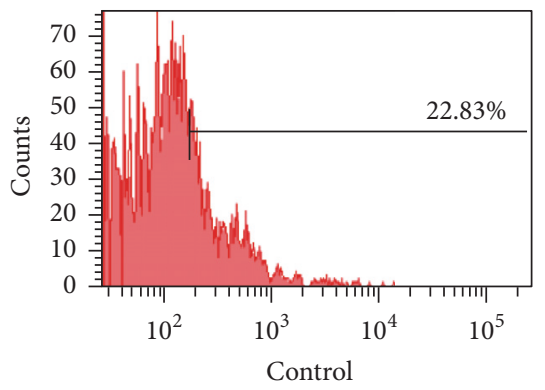

Dichlorofluorescein diacetate

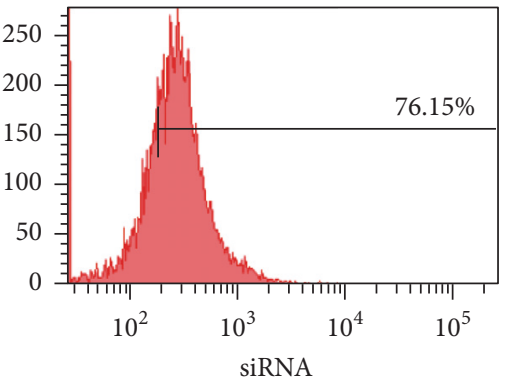

Dichlorofluorescein diacetate

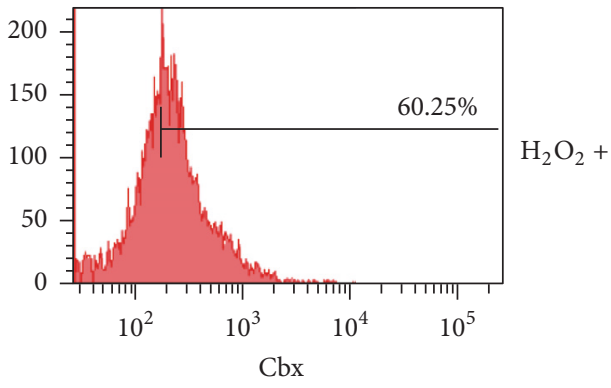

Dichlorofluorescein diacetate

FIGURE 3: siRNA knockdown or blocking $\mathrm{Cx} 43$ by $\mathrm{Cbx}$ enhanced $\mathrm{H}_{2} \mathrm{O}_{2}$ induced ROS production in astrocytes. ROS generation (\%) was measured using ROS-sensitive fluorometric probe 2,7-dichlorofluorescein diacetate (DCFDA) by flow cytometry.



(a)

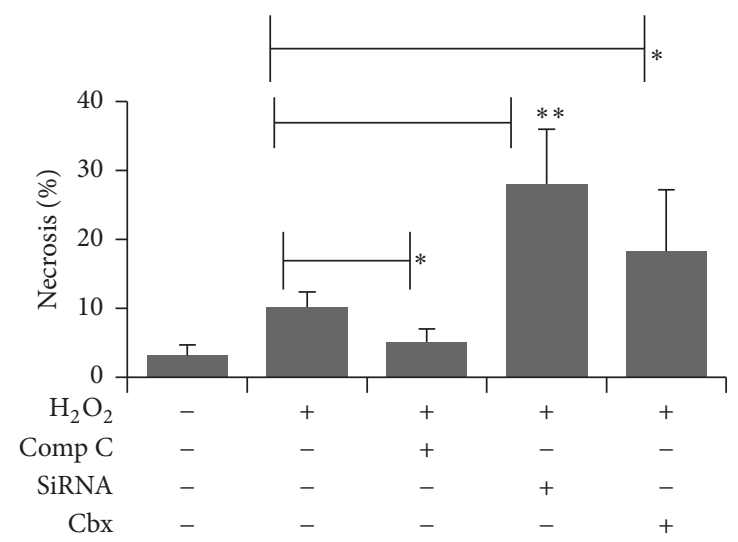

(c)



(b)



(d)

FIGURE 4: Attenuating $\mathrm{H}_{2} \mathrm{O}_{2}$-induced necrosis in astrocytes cell was involved in AMPK signal pathway. (a) $\mathrm{H}_{2} \mathrm{O}_{2}$-induced p-AMPK signal protein expression. (b) Quantification of p-AMPK/AMPK by membrane intensity. (c) Necrosis was determined using Annexin V FITC and PI double staining by flow cytometry. (d) ROS production was measured using DCFDA staining by flow cytometry. $*$ indicated $p<0.05 ; * *$ indicated $p<0.01$. 


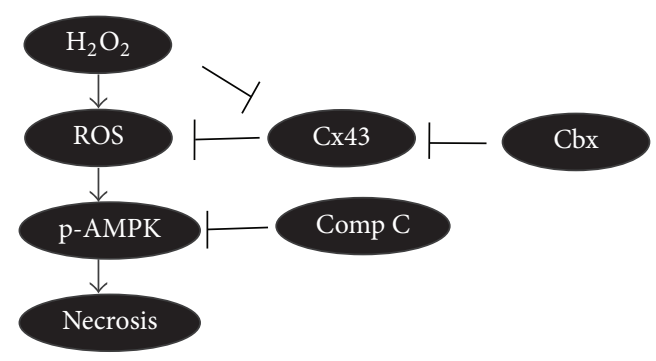

FIGURE 5: Molecular mechanism model. Cx43 plays its role in $\mathrm{H}_{2} \mathrm{O}_{2}$ induced ROS production and necrosis through activation of AMPK in astrocytes.

the apoptosis phenotype. These observations indicate that $\mathrm{H}_{2} \mathrm{O}_{2}$-induced injury was specific and might be correlated with $\mathrm{Cx} 43$ expression level.

To this end, siRNA target $\mathrm{Cx} 43$ gene or pharmacologically blocking $\mathrm{Cx} 43$ expression was tested. It is not surprising to see the decreased $\mathrm{Cx} 43$ expression. However, the question here is that $\mathrm{H}_{2} \mathrm{O}_{2}$-induced cell injury was not clear. The flow cytometry analysis with double staining could well distinguish cell apoptosis and necrosis. The results indicated that $\mathrm{H}_{2} \mathrm{O}_{2}$ induced both cell apoptosis and necrosis. Multiple cascade kinases are involved in those processes [21], while knockdown or blocking $\mathrm{Cx} 43$ resulted in mainly cell necrosis, as well as a small portion apoptosis. Thus, $\mathrm{Cx} 43$ protected against $\mathrm{H}_{2} \mathrm{O}_{2}$-induced necrosis, indicating that antinecrosis effect of $\mathrm{Cx} 43$ expression was present in normal astrocytes.

Increased $\mathrm{Cx} 43$ expression as a potential mediator to improve the neuroprotective activity was also widely investigated. The ROS production was another important index to the homeostasis. Environment stress leading to ROS increased dramatically, which resulted in significant damage to cells. Here, ROS production was increased, and inhibition of $\mathrm{Cx} 43$ expression enhanced the production. This result is similar to cell apoptosis and necrosis assay, which suggested the crucial role of $\mathrm{Cx} 43$ in both processes. Effect of ROS on cell metabolism including apoptosis is well documented in a variety of species [22].

Although $\mathrm{H}_{2} \mathrm{O}_{2}$ affected cell necrosis and ROS production significantly, less was known about its relation with AMPK that plays a leading role in cellular energy homeostasis. Astrocytes treated with $\mathrm{H}_{2} \mathrm{O}_{2}$ activate AMPK phosphorylation, which results in increasing of cell necrosis as concluded in Figure 5. We observed that AMPK activation after $\mathrm{H}_{2} \mathrm{O}_{2}$ treatment could be inhibited by its inhibitor Comp C, which significantly reduced cell necrosis and ROS production by $\mathrm{H}_{2} \mathrm{O}_{2}$. It suggests that AMPK activation favors cell death in ROS stressed. Similarly, we also found that knockdown $\mathrm{Cx} 43$ by siRNA or by its inhibitor Cbx could significantly enhance $\mathrm{H}_{2} \mathrm{O}_{2}$-induced damage. These data strongly argued that $\mathrm{Cx} 43$ had shown resistant effect in $\mathrm{H}_{2} \mathrm{O}_{2}$ stressed astrocytes and it is AMPK phosphorylation dependent.

In all, our study adds a novel connection to the mechanism of AMPK phosphorylation and cell apoptosis and necrosis in Cx43-regulated $\mathrm{H}_{2} \mathrm{O}_{2}$ resistance. We show that $\mathrm{Cx} 43$ expression plays a crucial role in protection against $\mathrm{H}_{2} \mathrm{O}_{2}$ injury. Several of the key points have been reported previously, which include $\mathrm{H}_{2} \mathrm{O}_{2}$-treated decreased cell viability, the reduction expression of $\mathrm{Cx} 43$ expression, and the neuroprotective actions of $\mathrm{Cx} 43$. Our data link these previous observations into a new view. Further experiments are needed to well elucidate the important function of $\mathrm{Cx} 43$ as an intracellular signaling molecule, with the differential sensitivity of $\mathrm{Cx} 43$ overexpressing astrocytes and downstream gene under AMPK triggered in this process.

\section{Conflicts of Interest}

The authors declare no conflicts of interest.

\section{Authors' Contributions}

Chunshan Zhao and Chunguo Li performed the experiment; Chunshan Zhao and Min Zhang wrote the manuscript.

\section{Acknowledgments}

This work was partially supported by the National Natural Science Foundation of China (81541168).

\section{References}

[1] A. Alvarez-Buylla, J. M. García-Verdugo, and A. D. Tramontin, "A unified hypothesis on the lineage of neural stem cells," Nature Reviews Neuroscience, vol. 2, no. 4, pp. 287-293, 2001.

[2] M. Bélanger and P. J. Magistretti, "The role of astroglia in neuroprotection," Dialogues in Clinical Neuroscience, vol. 11, no. 3, pp. 281-296, 2009.

[3] H. T. Le, W. C. Sin, S. Lozinsky et al., "Gap junction intercellular communication mediated by connexin 43 in astrocytes is essential for their resistance to oxidative stress," The Journal of Biological Chemistry, vol. 289, no. 3, pp. 1345-1354, 2014.

[4] N. J. Maragakis and J. D. Rothstein, "Mechanisms of Disease: astrocytes in neurodegenerative disease," Nature Clinical Practice Neurology, vol. 2, no. 12, pp. 679-689, 2006.

[5] J. E. Contreras, H. A. Sánchez, L. P. Véliz, F. F. Bukauskas, M. V. L. Bennett, and J. C. Sáez, "Role of connexin-based gap junction channels and hemichannels in ischemia-induced cell death in nervous tissue," Brain Research Reviews, vol. 47, no. 1-3, pp. 290 303, 2004.

[6] B. Poljsak, D. Šuput, and I. Milisav, "Achieving the balance between ROS and antioxidants: when to use the synthetic antioxidants," Oxidative Medicine and Cellular Longevity, vol. 2013, Article ID 956792, 11 pages, 2013.

[7] T. Krieg, L. Cui, Q. Qin, M. V. Cohen, and J. M. Downey, "Mitochondrial ROS generation following acetylcholine-induced EGF receptor transactivation requires metalloproteinase cleavage of proHB-EGF," Journal of Molecular and Cellular Cardiology, vol. 36, no. 3, pp. 435-443, 2004.

[8] S. F. Giardina, M. Mikami, F. Goubaeva, and J. Yang, "Connexin 43 confers resistance to hydrogen peroxide-mediated apoptosis," Biochemical and Biophysical Research Communications, vol. 362, no. 3, pp. 747-752, 2007.

[9] S. Schildge, C. Bohrer, K. Beck, and C. Schachtrup, "Isolation and culture of mouse cortical astrocytes," Journal of Visualized Experiments, no. 71, 2013. 
[10] Z. Min, H. Zhao, F. Luo, L. Su, and W. Shi, "IGF-II inhibitory DNAzymes inhibit the invasion and migration of hepatocarcinoma cells," Biotechnology Letters, vol. 33, no. 5, pp. 911-917, 2011.

[11] D. A. Iacobas, S. Iacobas, M. Urban-Maldonado, E. Scemes, and D. C. Spray, "Similar transcriptomic alterations in $\mathrm{Cx} 43$ knockdown and knockout astrocytes," Cell Communication \& Adhesion, vol. 15, no. 1-2, pp. 195-206, 2008.

[12] D. Wu and P. Yotnda, "Production and detection of reactive oxygen species (ROS) in cancers," Journal of Visualized Experiments, no. 57, 2011.

[13] L. Chen, G. Zhu, D. Zhang et al., "Novel mesoporous silica spheres with ultra-large pore sizes and their application in protein separation," Journal of Materials Chemistry, vol. 19, no. 14, pp. 2013-2017, 2009.

[14] Y. Xu, G. Wang, C. Li et al., "Pu-erh tea reduces nitric oxide levels in rats by inhibiting inducible nitric oxide synthase expression through toll-like receptor 4," International Journal of Molecular Sciences, vol. 13, no. 6, pp. 7174-7185, 2012.

[15] H. Zhao, M. Zhang, L. Zhao, Y.-K. Ge, J. Sheng, and W. Shi, "Changes of constituents and activity to apoptosis and cell cycle during fermentation of tea," International Journal of Molecular Sciences, vol. 12, no. 3, pp. 1862-1875, 2011.

[16] J. H. Lin, J. Yang, and S. Liu, "Connexin mediates gap junctionindependent resistance to cellular injury," The Journal of Neuroscience, vol. 23, pp. 430-441, 2003.

[17] J. Chen, S. Sun, D. Zha et al., "Soyasaponins prevent H2O2induced inhibition of gap junctional intercellular communication by scavenging reactive oxygen species in rat liver cells," Nutrition and Cancer, vol. 66, no. 8, pp. 1342-1351, 2014.

[18] D. I. Brown and K. K. Griendling, "Regulation of signal transduction by reactive oxygen species in the cardiovascular system," Circulation Research, vol. 116, no. 3, pp. 531-549, 2015.

[19] J. H.-C. Lin, N. Lou, N. Kang et al., "A central role of connexin 43 in hypoxic preconditioning," The Journal of Neuroscience, vol. 28, no. 3, pp. 681-695, 2008.

[20] O. Rom, N. Volkova, S. Nandi, R. Jelinek, and M. Aviram, "Pomegranate Juice Polyphenols Induce Macrophage Death via Apoptosis as Opposed to Necrosis Induced by Free Radical Generation: A Central Role for Oxidative Stress," Journal of Cardiovascular Pharmacology, vol. 68, no. 2, pp. 106-114, 2016.

[21] R. Hanstein, J. Trotter, C. Behl, and A. B. Clement, "Increased connexin 43 expression as a potential mediator of the neuroprotective activity of the corticotropin-releasing hormone," Molecular Endocrinology, vol. 23, no. 9, pp. 1479-1493, 2009.

[22] T. P. A. Devasagayam, J. C. Tilak, K. K. Boloor, K. S. Sane, S. S. Ghaskadbi, and R. D. Lele, "Free radicals and antioxidants in human health: current status and future prospects," Journal of the Association of Physicians of India, vol. 52, pp. 794-804, 2004. 

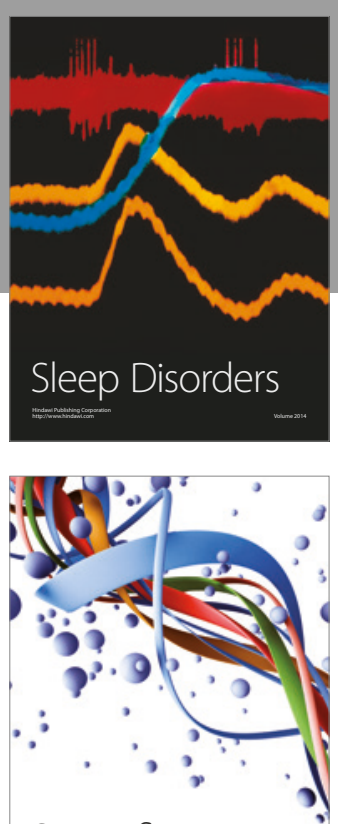

Scientifica
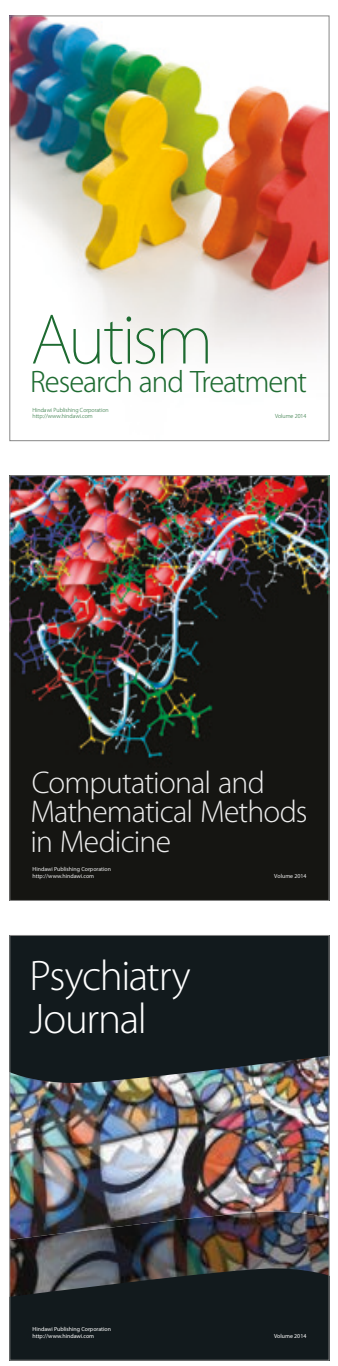


\section{Hindawi}

Submit your manuscripts at

https://www.hindawi.com
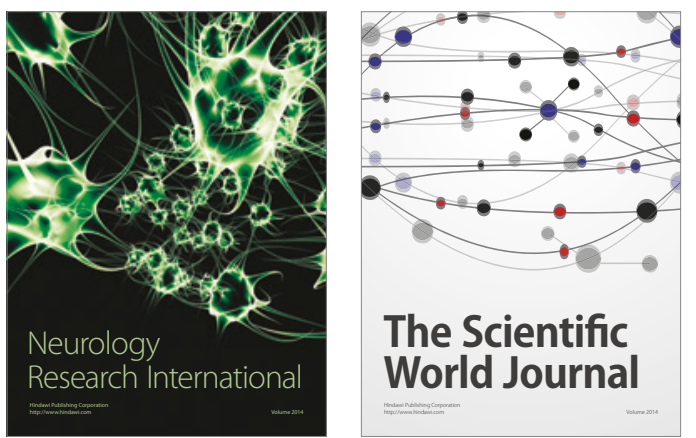

The Scientific World Journal

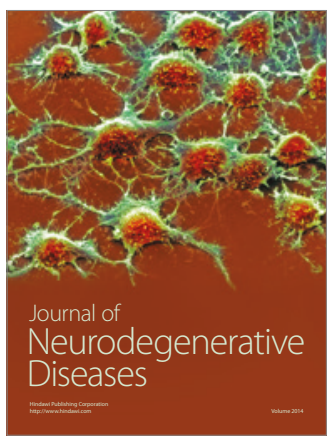

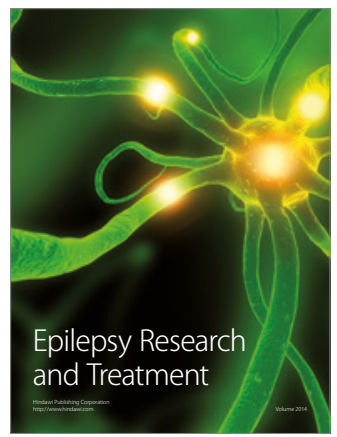



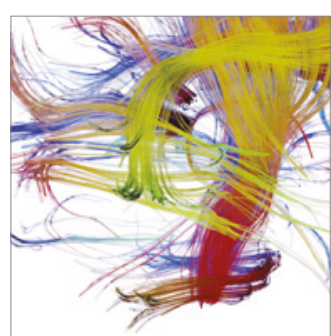

Brain Science

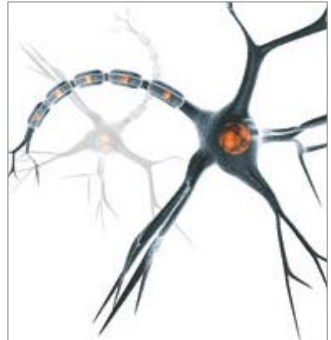

Neural Plasticity
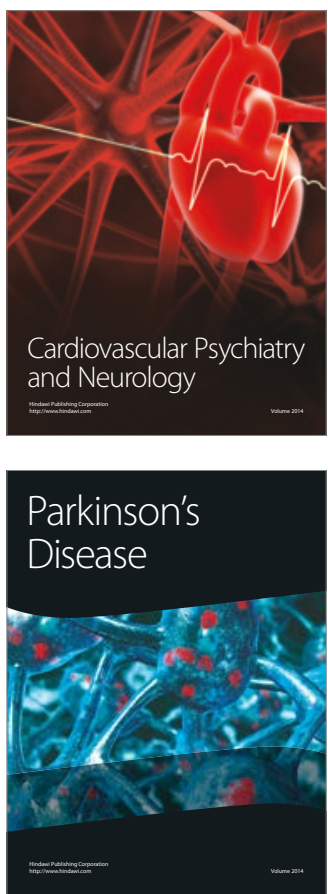